シンポジウム $\mathrm{I}-1$

\title{
血管内皮細胞の免疫機能
}

一炎症性腸疾患を場として一

\section{大谷 明夫，名倉宏}

東北大学医学部第二病理

The Immunologic function of vascular endothelial cells in inflammatory bowel disease

Haruo Ohtani, Hiroshi Nagura

Department of Pathology, Tohoku University School of Medicine

To evaluate immunologic function of vascular endothelial cells, we have set up an immunohistochemical study on the adhesion molecules in inflammatory bowel disease (IBD). In IBD, vascular endothelial cells became morphologically active; ie., they became swollen and had well developed cell organelles. Intercellular adhesion molecule -1 (ICAM-1) was expressed in plasma cells, lymphocytes, macrophages and vascular endothelial cells. Its counter-receptor, lymphocyte function associated antigen (LFA-1) was localized in lymphocytes. The expression of these molecules increased remarkably in IBD than in the normal intestinal or colonic mucosa. MHC class II antigen was also expressed abundantly in IBD. Vascular endothelial cells of venules expressed endothelial leukocyte adhesion molecule-1 (ELAM-1) in active inflammatory phase. Its expression was sporadic in the resolving phase of inflammation and the normal mucosa. Our study suggests that vascular endothelial cells regulate the permeation of inflammatory cells into the tissue from the blood by expressing the adhesion molecules. The common expression of ICAM-1 and HLA-DR antigens with macrophages indicates the presence of a unit of endothelial cells and macrophages in eliciting and/or maintaining the inflammation.

Key words: Adhesion molecules, Inflammatory bowel disease, Immunohistochemistry, Venules

\section{はじめに}

血管内皮細胞は血液を通す管である血管の内面を 被覆し, 血液と組織を境界している。しかし, 近年 この内皮細胞が単に異なったふたつの環境を境する のみならず，以下に述べる種々の機能を営んでいる
ことが明らかにされつつある。すなわち，血漿成分 透過；結合組織成分合成；凝固調節；血管トーヌス 調節；代謝調節；炎症・免疫反応の調節である。こ の際, 内皮細胞はサイトカイン・増殖因子などの生 理活性物質の合成・分泌に深く関与している ${ }^{1)}$ 。

炎症・免疫への関わりでは, 内皮細胞は細胞外基 
質あるいは血中からの抗原刺激を受け，自己・非自 己の認識をおこない, 免疫担当細胞への情報伝達を 営んでいるとされている。それに関与するのは内皮 細胞に表出されている，MHC Class II抗原や IL-1 といった，免疫機能分子である11。さらにこれについ ては近年, 接着分子の観点からのアプローチが盛ん である。接着分子は cell-cell contactをつかさどる 物質である。免疫現象に関わるものとしては三つに 大別されている2。a）免疫グロブリン (Ig) スーパ ーファミリ，b) インテグリンファミリ $(\alpha, \beta$ 鎖よ りなる), c ) LECAM ファミリ(レクチン様, EGF 様, 補体結合様のドメインを有する)。これらは, 白 血球, 内皮細胞, 抗原提示細胞, 一部上皮細胞など に発現される2。われわれは, 今回 Ig superfamily に 属する ICAM-13) (intercellular adhesion molecule), integrin family飞属するLFA-14) (lymphocyte function-associated antigen) (CD11a/CD18), そしてLECAM familyに属する ELAM-1 ${ }^{5)}$ (endothelial leukocyte adhesion molecule)をとりあげた。ICAM-1 と LFA-1 は receptor -counter receptor の関係にある。また, ELAM-1 は 好中球の糖鎖 sialyl Le $\mathrm{e}^{x}$ をガンドとしてい る6)7)。本稿では, 炎症性腸疾患をモデルとしてとり あげ，血管内皮細胞の炎症・免疫反応への関わりに ついて著者らの観察を中心に, 内外の報告をあわせ 紹介し，その重要性を論じたい。

\section{材 料と方 法}

\section{1. 免疫組織化学用}

潰瘍性大腸炎 10 例 (男 7 , 女 3 例, 平均年歯 31 歳) およびクローン病 10 例（男 5 , 女 5 例, 平均年齢 34 歳）の手術切除材料を用いた。標本は病変部より採 取し, 直ちに periodate-lysine-paraformaldehyde (PLP) 固定液にいれ，6〜10時間固定した。ショ糖加 PBS で洗浄の後, OCT compound に包埋し, 凍結 した。厚さ $6 \mu$ の凍結切片上で酵素抗体間接法を用い た。使用した抗体は表 1 に示した。二次抗体は $\mathrm{F}\left(\mathrm{ab}^{\prime}\right)_{2}$ フラグメントに HRPを標識したものを用 いた (Amersham)。

酵素抗体二重染色は biotin-streptavidin 法 (ヒス トファインキット, ニチレイ)を用い, 第一回目は AEC (Vector)，第二回目は 4-chloro-1-naphtol で 発色した。両免疫反応のあいだでは, 切片をグリシ ン緩衝液で30分洗浄し，さらに，内因性ビオチンブ ロックキット（Vector）をもちいて，第一回目の二
表 1 使用した抗体
anti-ICAM-1 (Immunotech)
anti-LFA-1 (CD11a) (Nichirei)
OKM5 (CD36) (Ortho)
anti-ELAM-1 (British-Biotechnology)
M718 (CD68) (DAKO)
anti-S100 protein (DAKO)

次抗体のビオチンをブッロクした。免度電顕用には 酵素抗体間接法で同様におこなった。

通常電顕用には潰瘍性大腸炎 5 例を用いた。生検 材料を招もに用いた。2.5\% glutaraldehyde $2 \%$ paraformaldehyde で 2 時間固定し， $1 \%$ osmium tetroxideで後固定し, 常法にてェポン包埋した。1 $\mu$ 切片で観察部位のオリエンテーションをして, 超 薄切片をウランー鉛で重染し, 電顕観察した。

\section{結果}

1. 内皮細胞の活性化現象一炎症に伴う血管構造 変化

正常大腸粘膜の血管は毛細血管が主体を占めてい た。その毛細血管では内皮細胞が薄くその小器官は そしかった（Fig. 1)。これに対し，炎症の強い部分 では血管増殖が引き起こされ, 内腔の狭い毛細血管 の増加とともに, 内腔の広い小静脈が増殖していた。 内皮細胞は一般に大型化していた（Fig. 2)。

\section{ICAM-1 と LFA-1 の免疫組織化学}

正常大腸粘膜固有層では, ICAM-1 は血管内皮細 胞にのみ発現していた（Fig. 3a）。LFA-1 は散在性 に存在するリンパ球にのみ認められた（Fig. 4a)。

潰瘍性大腸炎もクローン病ともそれらの粘膜組織 に招いて, 炎症の程度にほほ比例して, ICAM-1, LFA-1 陽性細胞の出現・増加を認めた（Figs. 3b, 4b)。ICAM-1 は血管内皮細胞(ことに小静脈につよ い）と形質細胞・マクロファージを含む炎症性細胞 に表出されていた。なお一次リンパ濾胞のリンパ球 は陰性だった。一部, 腺上皮にも ICAM-1 陽性像が 観察された。LFA-1 は打もに単核球系細胞に発現し ていた。炎症緩解期ではこれらの発現は少なかった。 免疫電䫓では ICAM-1 は血管内皮内腔面 (一部内皮 細胞核周囲腔）扣よび, リンパ球, 形質細胞, マク ロファージ様細胞の細胞膜に陽性であった。MHC class II 抗原の表出もこれらと同様であった（Figs. 


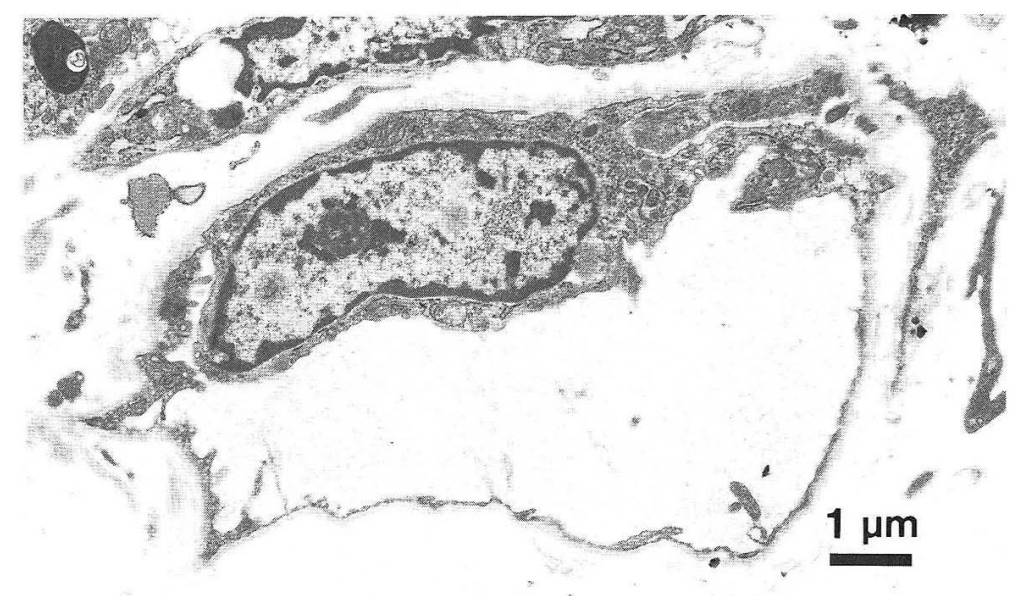

Fig. 1 正常大腸粘膜固有層の毛細血管

内皮細胞の小器官は発達せず，核のない部分の細胞質は薄く，血 液を通す“くだ”として合理的な形状を呈している。

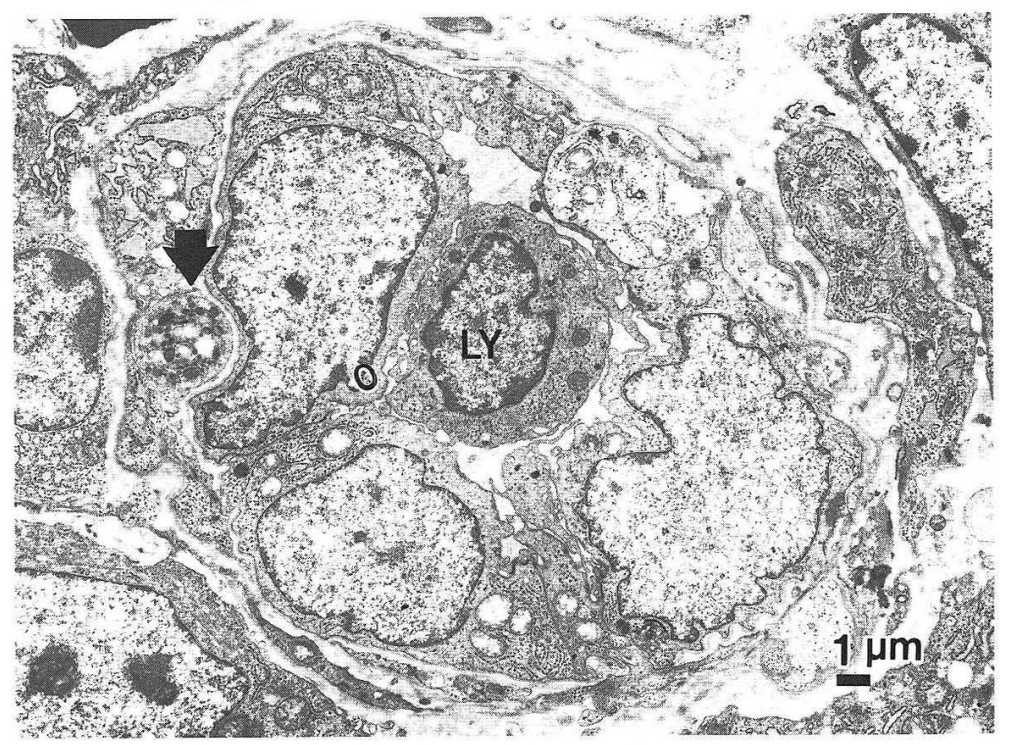

Fig. 2 潰眺性大腸炎肉芽組織での小血管(venule) 形態的活性化が明らかである。内腔に顆粒を有するリンパ球の付 着を認め (Ly), 矢印は内皮細胞と pericyte の間の顆粒球(の一部) を示す。

$5 a, 5 b)$ 。

3. マクロファージ系細胞との関連

免疫重染色では, CD68+マクロファージは正常大 腸粘膜では ICAM-1(-)であるのに対し, 炎症巣では
ICAM-1(+)であった。S-100+樹枝状細胞も ICAM-1 (十)であった。また, 正常粘膜に比較し炎症性腸疾患 では CD68+マクロファージは有意に増加し（約 2.4 倍), S- $100^{+}$樹枝状細胞は正常粘膜ではほとんど存 
Fig. 3 ICAM-1 の免疫組織化学

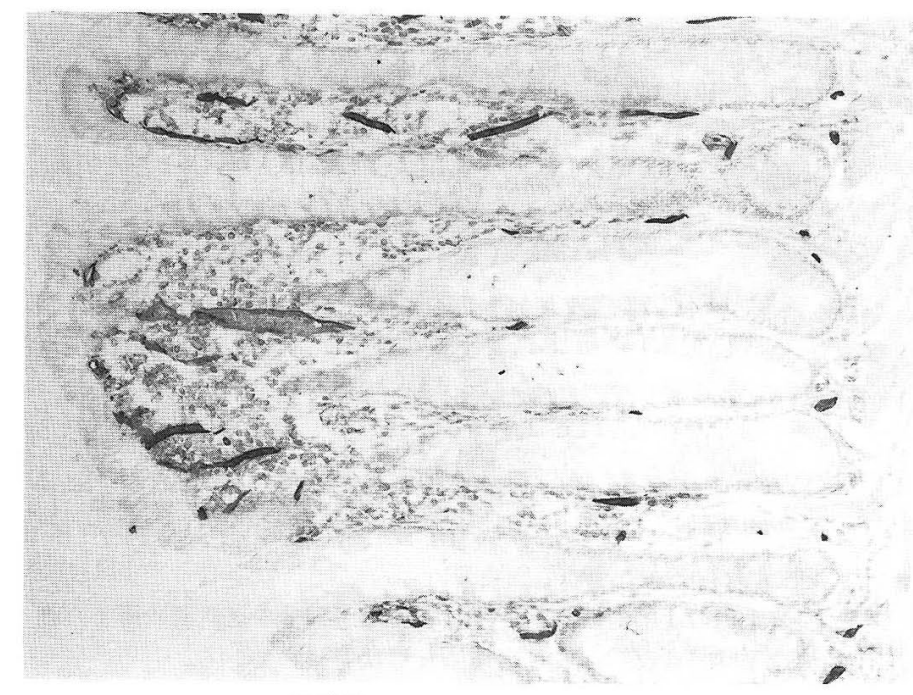

a 正常粘膜。お方もに，血管が陽性。 $\times 110$

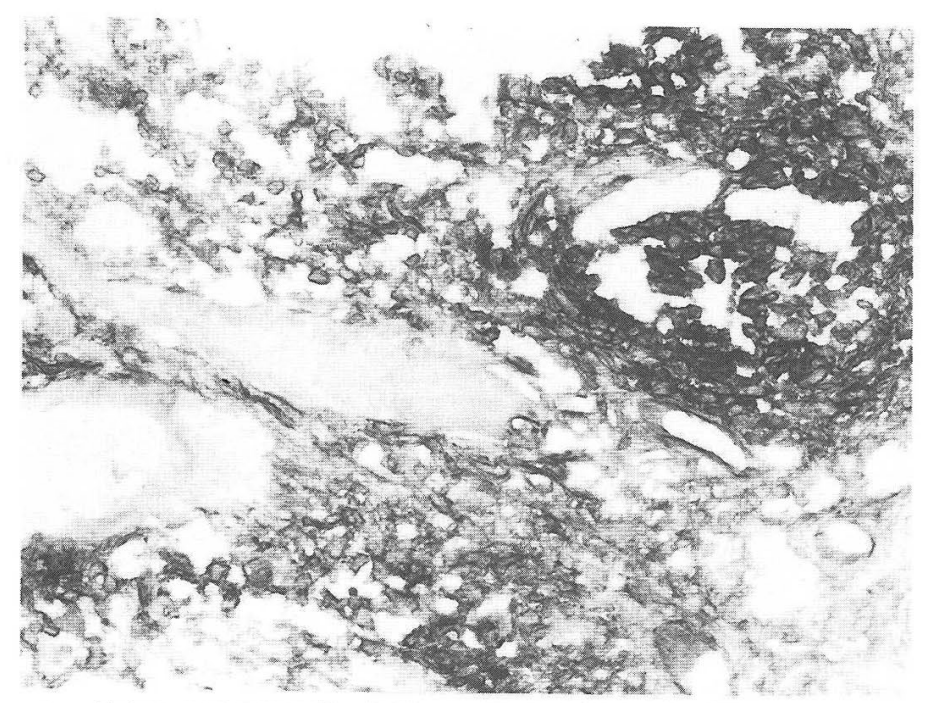

b 漬瘍性大腸炎活動期の粘膜。浸潤細胞多数と血管が陽性。 $\times 220$

在しなく, 炎症巣での出現増加が明らかであった(以 上のデータはNakamura et al., manuscript in preparation)。

4. ELAM-1 の免疫組織化学

炎症の強い部位に括いてのみ，小静脈を中心とす る血管に陽性となった（Fig. 6)。また，多くの好中 球がこれらの血管内腔とその周囲に観察された。炎 症緩解巣では ELAM-1 の陽性血管は小数であっ た。正常血管はほとんど陰性であった。
免疫電顕的には ELAM-1 は内皮細胞の内腔面に 陽性であった（Fig. 7)。また内皮細胞の発達した粗 面小胞体, 円形顆粒も陽性であった。血管内腔への 開口分泌像も認めた。

5.リンパ組織での結果

リンパ節とパイェル板では, ICAM-1 は胚中心の リンパ球と樹状細胞および血管内皮細胞に陽性だっ た。LFA-1はおもに ELAM-1は T-zone の high endothelial venule 
Fig. 4 LFA-1 の免疫組織化学

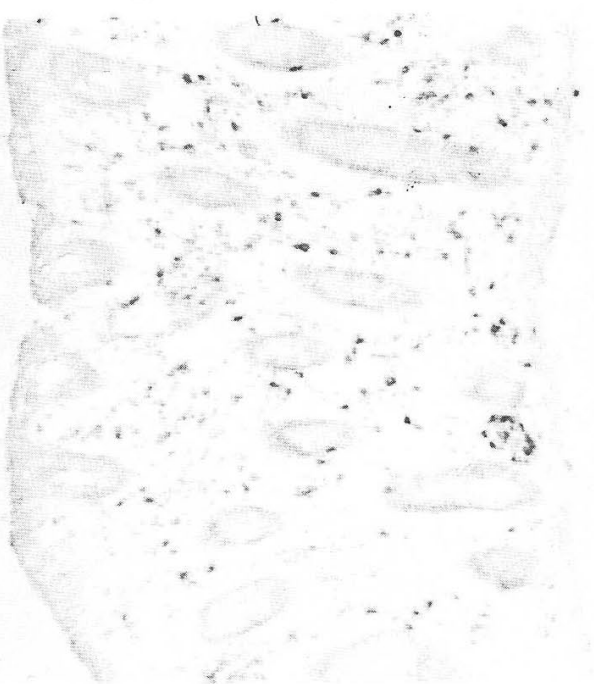

a 正常大腸粘膜。リンパ球が散在性に陽性。 $\times 110$

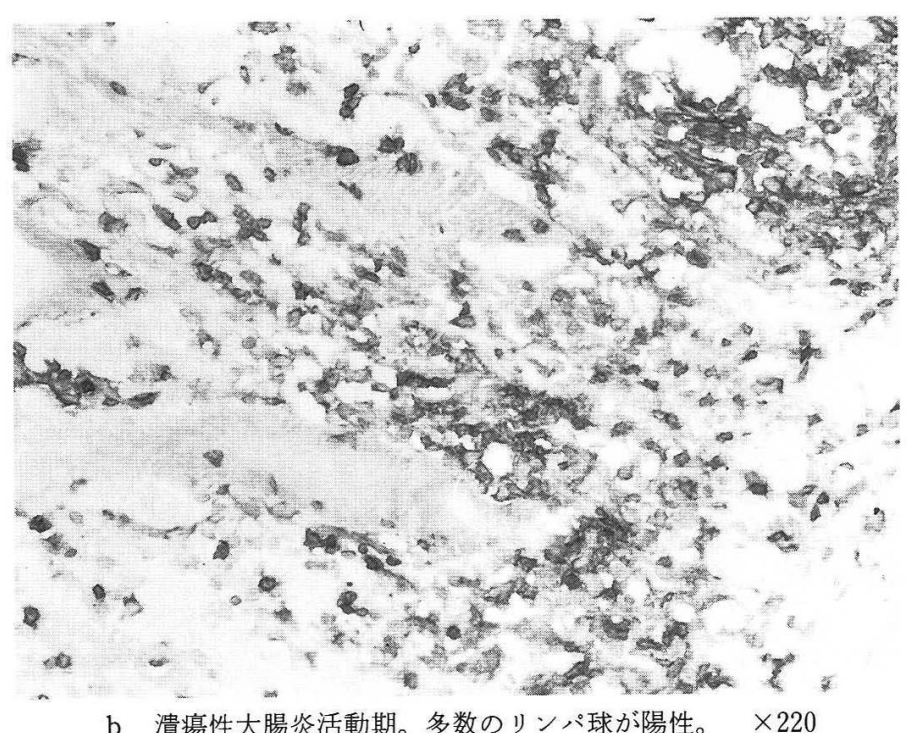

b 潰瘍性大腸炎活動期。多数のリンパ球が陽性。 $\times 220$

（HEV）の一部に局在した。

考

察

炎症反応は, 白血球問, 白血球一血管内皮細胞間, 白血球一抗原提示細胞間の複雑な相互作用により司 られており, 接着分子はこれらの細胞間相互作用を 調節している。今回とりあげた LFA-1 ははじめ細 胞傷害性リンパ球の細胞傷害活性を阻害する抗体と して報告された4)。これはインテグリンファミリに
属する糖蛋白で, ほとんどの白血球に分布している。 また ICAM-1はLFA-1 の counter receptor とし て同定された ${ }^{3)}$ 。れはIg superfamilyに属する糖 蛋白で, 血管内皮細胞, 線維芽細胞, 上皮細胞に発 現して抢り，末梢白血球では汪とんど発現されてい ない。咨症性サイトカイン (IL-1, TNF, INF- $\gamma$ ) によりこれら細胞にも ICAM-1 が誘導される8)。血 管内皮細胞での ICAM-1 の発現は正常でもみられ るが，炎症性サイトカインの刺激を受けると，その 
Fig. 5 HLA-DR 免疫染色

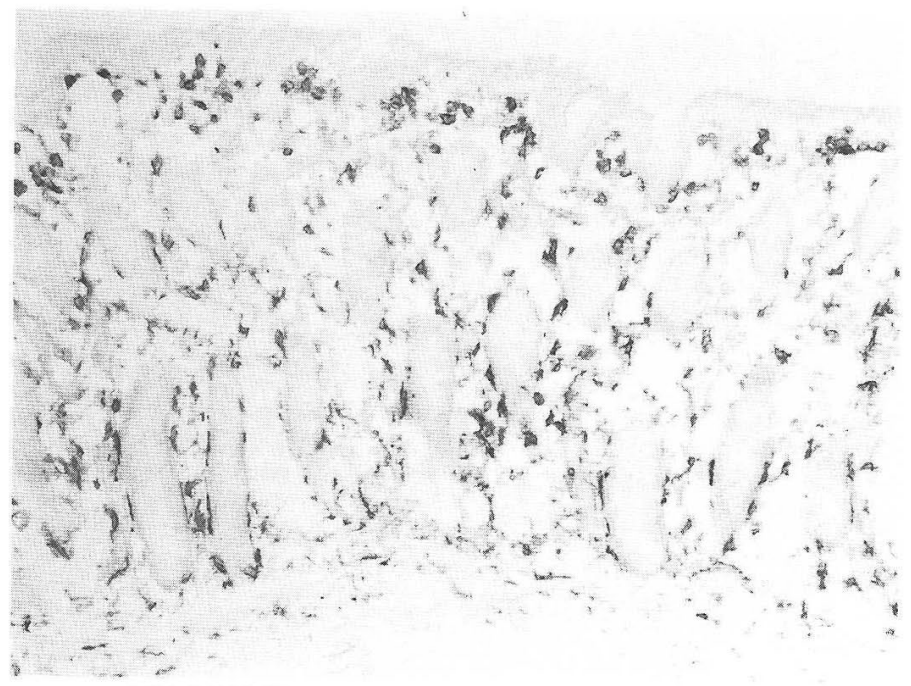

a 正常大腸粘膜。リンパ球, マクロファージ, 血管が陽性。

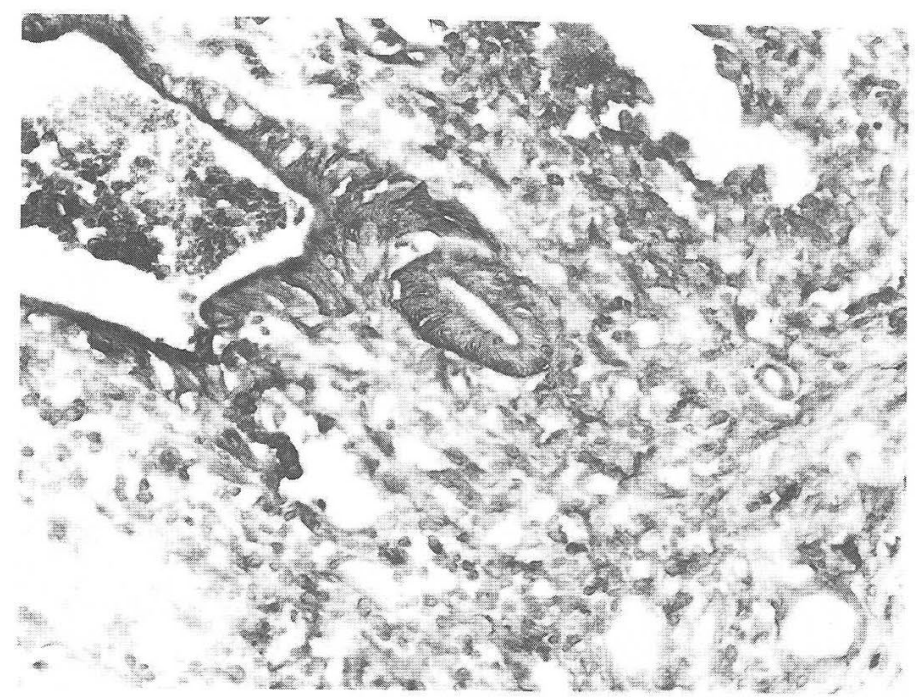

b 潰瘍性大腸炎活動期。多数の浸潤細胞と血管, および上皮 細胞が陽性。 $\times 220$

発現が増加することが知られている。このことは， LFA-1 陽性白血球の炎症巣での血管外移動に重要 な働さをしていることが示㖫される。今回の結果で も炎症性腸疾患に括いて炎症の程度に応じて, ICAM-1 陽性炎症性細胞増加が観察された。このこ とは，炎症性サイトカインが働いていることを示唆 している。筆者らの観察結果は他の七ト炎症性疾患 での報告と一致する ${ }^{9)}$ 11)。また，その結果としての
LFA-1 陽性白血球の增加は予想されると打りであ る。

抗原提示細胞としてのマクロファージと樹状細胞 が炎症性疾患で増加し，しかもマクロファージに ICAM-1 の発現が付与されていることは, リンパ球 との接着をICAM-1 と LFA-1 が促進しているこ とを示唆している(つまり, 抗原/MHC-TCR/CD3 の接着を抗原非依存性に補助していると考えられ 


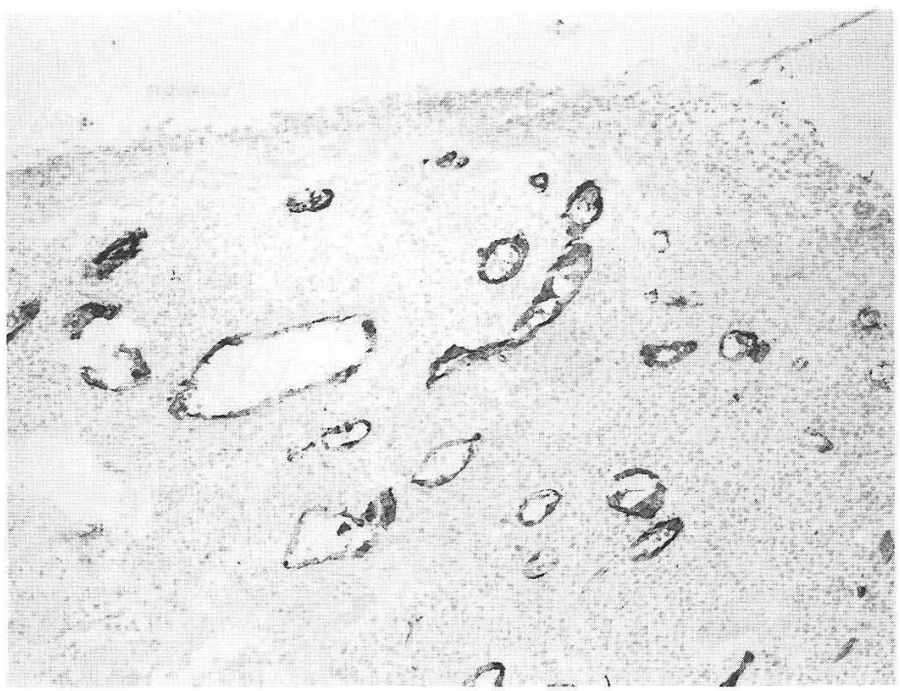

Fig. 6 ELAM-1 免疫染色

潰瘍性大腸炎の潰痬部肉芽組織。小静脈が陽性。

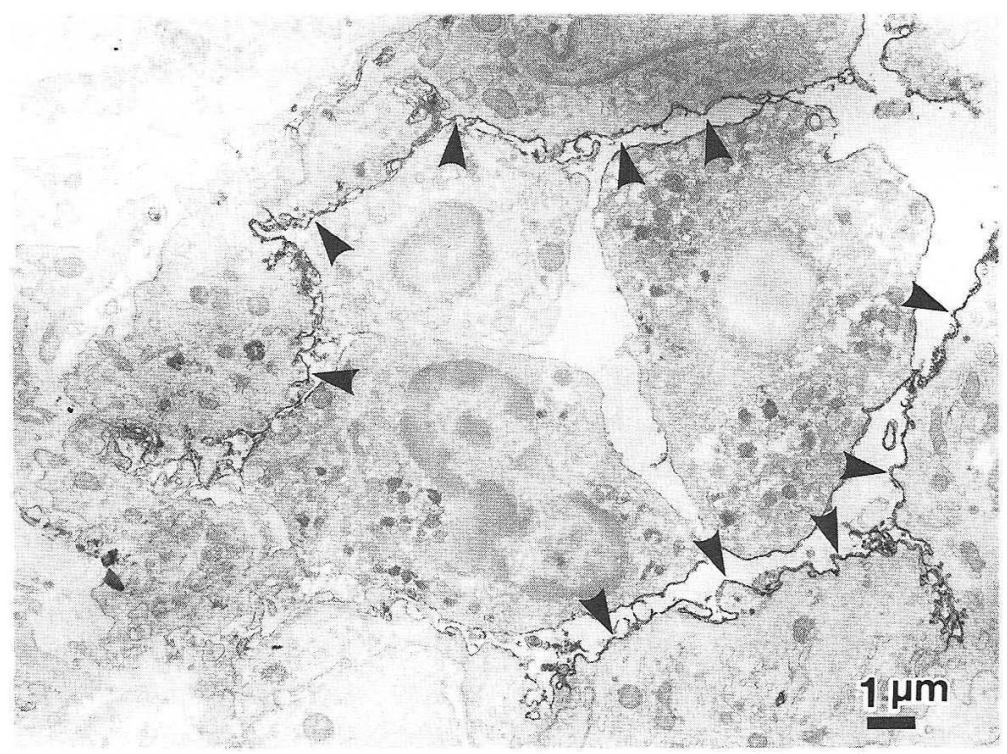

Fig. 7 ELAM-1 の免疫電顥

クローン病での炎症部粘膜。小静脈内皮細胞の内腔面に陽性。 内腔には炎症性細胞を認める。なお，血管内皮細胞での ICAM -1 と HLA-DR の表出も内腔面に沿っておこなわれ，この所見 と似ている。この浪か, ELAM-1 は内皮細胞の粗面小胞体や顆 粒にも陽性である。 


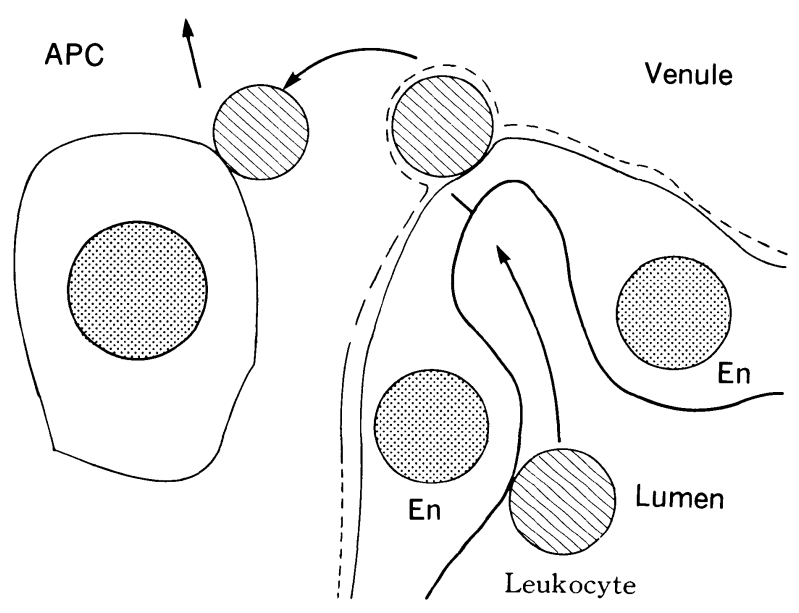

Fig. 8 血管内皮細胞 (En) と抗原提示細胞 (APC) における炎症 性細胞に対する接着分子の表出のまとめ

太線が接着分子の表出部位。炎症性細胞が血管透過の時点 と APC との接着に打いて，接着分子が働くことを示し ている。本稿では太線はICAM-1(あるいはHLA-DR) に相当する。counter - receptor は LFA-1（あるいは CD4)である。内皮細胞とマクロファージとはこのよらな 機能的共通性を有して扔り, 炎症巣形成に批ける一つの単 位としてとらえることが可能である。

る1213))。

ELAM-1 は资症性サイトカインにより急速に誘 導される内皮細胞上の接着分子である5)。レクチン 様ドメインを有し，好中球の糖鎖である sialyl $\mathrm{Le}^{\mathrm{x}}$ と結合する（な打興味あることに sialyl $\mathrm{Le}^{\mathrm{x}}$ は各種 腺癌の腫瘍マーカーとして以前より知られてい た ${ }^{14)}$ )。ずに急性炎症巣での小静脈で発現すること が知られている ${ }^{15)}$ 。今回の結論はこれと一致する。炎 症性腸疾患での好中球浸潤に打いて，血管内皮と好 中球の接着に関与していると考学られる。

\section{ま と め}

炎症巣の成立・維持において, 白血球の局所への 浸潤を司っているのは接着分子と考えられつつあ る。また，抗原提示細胞之白血球との接着にも深く 関与している。ICAM-1 がこの両者（内皮細胞と抗 原提示細胞）に発現していることは，この両者が機 能分子的に共通の役割をになっていることを示して いる。内皮細胞はこのように白血球浸出に関与しマ
クロファージ，樹状細胞と一つの群をなして免疫・ 炎症反応にかかわっていると考えている（Fig. 8)。 これが, 血管内皮の免度機能としての重要な一側面 である。

\section{今後の展開}

血管新生 (angiogenesis)が起こる代表は炎症と固 形癌である。今回炎症における血管内皮の役割を考 察した。本研究の示すように血管新生が単なる血管 の増加を意味しているのではないことは明らかであ る。では, 癌ではどうであろらか？ 単に癌の栄養 補給といら面でのみ考察しては扰そらく不十分であ ろら。癌間質でも血管内皮細胞が形態的にも機能面 でも変化していることはわれわれがすでに報告して きた16117)。今後この面からの検討が望まれる。

謝辞：大阪市立大学医学部第三内科 中村志郎先生 の協力に深く感謝します。 
文

1) Beilke MA: Vascular endothelium in immunology and infectious disease. Rev Infect Dis $11: 273-2831989$

2）宮坂昌之：血管内皮細胞へのリンパ球接着-Adhesion molecules. 病理と臨床 9 : 22-25 1991

3) Marlin SD, Springer TA : Purified intercellular adhesion molecule-1 (ICAM-1) is a ligand for lymphocyte function-associated antigen-1 (LFA -1). Cell $51: 813-8191987$

4) Krensky AM, Danchez-Madred F et al.: The functional significance, distribution and structure of LFA-1, LFA-2, and LFA-3 : cell surface antigens associated with CTL-target interactions. J Immunol 131:611-616 1983

5 ) Bevilacqua MP, Stengelin S, Gimbrone MA, Seed B:Endothelial leukocyte adhesion molecule I: an inducible receptor for neutrophils related to complement regulatory proteins and lectins. Science $243: 1160-11651989$

6) Lowe JB, Stoolman LM, Nair RP, et al. : ELAM -1 dependent cell adhesion to vascular endothelium determined by a transfected human fucosyltransferase cDNA. Cell 63:475-484 1990

7) Phillips ML, Nudelman E, Gaeta FCA et al.: ELAM-1 mediates cell adhesion by recognition of a carbohydrate ligand, sialyl-Lex. Science $250: 1130-11321990$

8 ) Dustin ML, Springer TA, et al. : Induction by IL -1 and IFN- $\gamma$ :tissue distribution, biochemistry and function of a natural adherence molecule (ICAM-1). J Immunol 137 :245-254 1986

9 ) Griffiths CEM, Nickoloff BJ :Keratinocyte intercellular adhesion molecule-1 (ICAM-1) expression precedes dermal $\mathrm{T}$ lymphocyte infiltration in allergic contact dermatitis (Rhus dermatitis). Am J Pathol 135 : 1045-1053 1989

\section{献}

10) Volpes R, Desmet VJ et al.: Immunohistochemical study of adhesion molecules in liver inflammation. Hepatology $12: 59-651990$

11) Sobel RA, Fondren $G$ et al. : Intercellular adhesion molecule-1 (ICAM-1) in cellular immune reactions in the human central nervous system. Am J Pathol 136:1309-1316 1990

12) Dastin ML, Springer TA : Lymphocyte functionassociated antigen-1 (LFA-1) interaction with intercellular adhesion molecule-1 (ICAM-1) is one of at least three mechanisms for lymphocyte adhesion to cultured endothelial cells. J Cell Biol $107: 321-3311988$

13) Malizia G, Calabrese A, et al.: Expression of leukocyte adhesion molecules by mucosal mononuclear phagocytes in inflammatory bowel disease. Gastroenteology 100:150-159 1991

14) Fukushi Y, Nudelman E et al. : Novel fucolipids accumulating in human adenocarcinoma. III a hybridoma antibody (FH6) defining a human cancer-associated difucoganglioside. J Biol Chem 259:10511 1984

15) Cotran RS, Gimbrone MA et al. Induction and detetection of a human endothelial activation antigen in vivo.J Exp Med $164: 661-6661986$

16) Ohtani $H$, Sasano $N$ : Characterization of microvasculature in the stroma of human colorectal carcinoma:an immunoelectron microscopic study on factor VIII/von Willebrand factor. J Electron Microsc 36 : 204-212 1987

17) Ohtani H, Nagura $H$ : Differing microvasculature in the two major types of gastric carcinoma: a conventional, ultrastructural and ultrastructural immunolocalization study of von Willebrand factor. Virchows Arch [A] $417: 29$ 351990 